\title{
Clarification of pomegranate juice by ultrafiltration: study of juice quality and of the fouling mechanism
}

\author{
Semia BAKLOUtI ${ }^{1 *}$, Raoudha ElLOUZE-GHORBEL ${ }^{2}$, Abir MoKNI ${ }^{2}$, Semia ChAABOUNI ${ }^{2}$
}

${ }^{1}$ Unité Rech. Chim. Ind. Matér., École Ntl. Ing. Sfax, BP W 3038, Sfax, Tunisia, semiabakloutibouzid@yahoo.fr

2 Unité Enzym. Bioconvers., École Ntl. Ing. Sfax, BP W 3038, Sfax, Tunisia

${ }^{*}$ Correspondence and reprints

Received 2 May 2011 Accepted 28 June 2011

Fruits, 2012, vol. 67, p. 215-225 (c) 2012 Cirad/EDP Sciences All rights reserved DOI: 10.1051/fruits/2012010 www.fruits-journal.org

Resumen Español, p. 225

\section{Clarification of pomegranate juice by ultrafiltration: study of juice quality and of the fouling mechanism.}

Abstract - Introduction. Ultrafiltration (UF) is a single-unit operation for the clarification and fining of fruit juices. The purpose of the UF is to remove suspended solids as well as haze-inducing and turbidity-causing substances to obtain a clear juice during storage. Specifically, the polymerization of phenolic compounds and their interaction with other components (e.g., proteins) could cause a haze complex and turbidity in fruit juices, which can foul the ultrafiltration membrane. Materials and methods. Fresh pomegranate juice was clarified by the ultrafiltration process on a laboratory scale. In experimental tests performed according to the total recycle and the batch concentration mode, the effects of transmembrane pressure (TMP) and enzyme pre-treatment on permeation flux and quality of juice were studied. Results. With the total recycle mode, the effect of TMP on the color and clarity of clarified pomegranate juice was significant. The initial color of the raw pomegranate juice was reduced from $74 \%$ to $33 \%$ and the clarity decreased from $77 \%$ to $42 \%$ by UF when the TMP increased from (1 to 3.6) bar. Total phenolic rejection decreased from $45 \%$ to $21 \%$ when the TMP rose from ( 1 to 2 ) bar and remained constant above this value. With the batch concentration mode at TMP $=2$ bar and velocity $1 \mathrm{~m} \cdot \mathrm{s}^{-1}$, the enzymatic treatment $\left(5 \mathrm{U} \cdot \mathrm{mL}^{-1}, 300 \mathrm{~min}, \mathrm{~T}=20^{\circ} \mathrm{C}\right)$ of pomegranate juice provided the highest permeate flux, a decrease in total phenolics of $50 \%$ and an increased clarity of $30 \%$. Fouling of the UF membrane during pomegranate juice processing is mainly due to the retention of polyphenols and/or proteins; thus, several blocking mechanisms were studied, using a recently developed membrane-fouling model. Analysis revealed that the membrane separation process was controlled by the gel layer mechanism of raw pomegranate juice and complete pore blocking mechanism with enzymatic pretreatment.

Tunisia / Punica granatum / fruit juices / clarifying / ultrafiltration / phenolic compounds / membranes / fouling / processing / laccase

\section{Clarification du jus de grenade par ultrafiltration : étude de la qualité du jus et du} mécanisme de colmatage.

Résumé - Introduction.L'ultrafiltration (UF) est un procédé simple pour la clarification et pour l'affinage de jus de fruits. Son objectif est d'éliminer les matières en suspension ainsi que les substances induisant trouble et turbidité pendant son stockage. Plus précisément, la polymérisation des composés phénoliques et leur interaction avec d'autres composants (des protéines, par exemple) pourraient causer du trouble et de la turbidité dans les jus de fruits, conduisant au colmatage de la membrane d'ultrafiltration. Matériel et méthodes. Un jus de grenade frais a été clarifié par ultrafiltration. Les essais expérimentaux ont été effectués en mode de recyclage total ou en batch par renvoi du retentât dans la cuve d'alimentation. Les effets de la pression transmembranaire (PTM) et d'un prétraitement enzymatique sur le flux de perméation et la qualité des jus ont été étudiés. Résultats. Avec le mode de recyclage total, l'effet de la PTM sur la couleur et la clarté du jus de grenade clarifié ont été significatifs. La couleur du jus de grenade brut a été réduite de $74 \%$ à $33 \%$ et sa clarté a diminué de $77 \%$ à $42 \%$ lorsque la PTM est passée de (1 à 3,6) bar. Le rejet des composés phénoliques a diminué de $45 \%$ à $21 \%$ lorsque la PTM est passée de (1 à 2) bar et a été maintenu constant au-dessus de 2 bar. En mode batch et pour une PTM de 2 bar et une vitesse de $1 \mathrm{~m} \cdot \mathrm{s}^{-1}$, le traitement enzymatique $\left(5 \mathrm{U} \cdot \mathrm{mL}^{-1}, 300 \mathrm{~min}, \mathrm{~T}=20^{\circ} \mathrm{C}\right)$ du jus de grenade a amélioré le f lux du perméat et a entrainé une diminution des composés phénoliques totaux de $50 \%$ et une augmentation de la clarté de $30 \%$. Le colmatage de la membrane d'UF lors du traitement de jus de grenade est principalement dû à la rétention des polyphénols et/ou de protéines ; par conséquent, plusieurs mécanismes de colmatage ont été étudiés, en utilisant un modèle de colmatage de membrane récemment développé. L'analyse a révélé que le procédé de séparation membranaire a été contrôlé par le mécanisme de la couche de gel pour le jus de grenade brut et par un mécanisme de blocage complet des pores pour le jus avec prétraitement enzymatique. Tunisie / Punica granatum / jus de fruits / clarification / ultrafiltration / composé phénolique / membrane / encrassement / traitement / laccase 


\section{Introduction}

Pomegranate (Punica granatum L.) is one of the oldest edible fruits, widely grown in many countries (Iran, India, Turkey, Tunisia, Pakistan and Spain). In Tunisia, it is cultivated in many regions such as Tunis, Zaghouan, Djerba, Gabes and Sfax. Its beneficial effects are attributed to the antioxidative properties of pomegranate phenolic compounds as well as to those of sugar-containing polyphenolic tannins [molecular weight $(\mathrm{MW})=500-3,000 \mathrm{Da}$ and anthocyanins (MW $=207.247 \mathrm{Da}$ ) There is growing interest in this fruit not only because of its pleasant taste but also because of scientific evidence that suggests the fruit's health-beneficial effects due to its composition. The recent studies on health benefits of consumption of pomegranate juice involve prevention or treatment of atherosclerosis, reduction of blood pressure, inhibition of cancer cell proliferation, anti-inflammatory effects, stimulation of T-cell functions and treatment of diabetes [1-3]. On the basis of these characteristics, pomegranate processing has recently been gaining more importance. Consumer acceptance of pomegranate juice depends on the combination of several quality attributes that are related to the physicochemical properties including color, acidity and flavor. Pomegranate fruit is consumed directly as fresh fruit or as juice. However, processing a safe, stable and highquality product which has the characteristics of fresh fruit, aroma and nutritional value is complicated; also, production has not been industrialized yet.

The edible part of the fruit contains considerable amounts of phenolic compounds. The bound phenolic constituents give color, astringency and bitterness to the pomegranate juice [4]. Since the main problem with pomegranate juice is stability, there is a need for research to solve this problem and, in addition, the preservation of color of the pomegranate juice [5]. According to the literature, the current methods for polyphenol elimination involve liquid extraction with organic solvents. However, these methods require high temperature to increase the extraction rate and yield but may denature the polyphenols [6].
Recent efforts have been devoted to evaluating processes based on membrane filtration due to their potential advantages in comparison with traditional processes, such as avoiding the use of fining agents (clarification) and not using high temperatures (concentration). The introduction of these technologies into the processing cycle of fruit juice can produce a clarified juice of high quality and fresh taste, nature-identical and additive-free. In particular, ultrafiltration (UF) represents a valid alternative to offer the possibility of clear filtering, sterile juices in one step, with and without the addition of clarifiers. Other advantages of the UF-based process are easy automation, lower labor and energy costs, and mild operating conditions. However, membrane filtration has the disadvantage of fouling, resulting in decline in performance. Indeed, a major limiting factor in UF is the flux decline with time due to the effects of membrane fouling, that reduce process efficiency [7]. The membrane structure and the molecular weight cut-off have an important role in the solute-membrane physicochemical interaction. All the compounds whose size is greater than the membrane pore size are accumulated on the membrane surface by convective transport, forming a concentration gradient known as the "polarized layer". The solute concentration increases on the interface until a dense cross-linked layer of deposited particles is formed round the membrane surface, which is known as the "gel layer". This dynamic layer is modified by operating conditions, such as crossflow velocity, transmembrane pressure (TMP) or concentration of feed solution [6, $8,9]$. In juice UF, membranes retain large species such as micro-organisms, lipids and colloids, while small solutes such as, for example, vitamins, salts, sugars and free phenolic compounds flow through the membrane together with water. Membrane fouling is caused mainly by large constituents of the juice such as pectin and polyphenol-protein complexes, which subsequently clog up the membranes. Treatment with enzymes helps to guarantee the complete hydrolysis of pectic substances, to minimize the risk of fouling of the costly membranes [10-15] and removal/degradation of polyphenolic compounds that are responsible for 
haze and sediment formation as well as browning during storage of juice [5, 16-18]. There are several studies in which enzyme treatment has been proven to show an improvement in juice clarification and stability over the conventional process. For example, laccase treatment was important in the removal of polyphenols [5]. During the enzymatic treatment, laccase catalyzes the oxidation of juice phenols to o-quinines, which are highly reactive compounds. They undergo spontaneous polymerization to produce high-molecular-weight compounds (brown pigments) [19]. These compounds could be discarded by centrifugation. On the other hand, low-molecularweight phenols (oligomers) remain in the supernatant and could lead to a darkening of the juice color which could easily be removed by membrane filtration $[5,20]$.

The objective of our investigation was to study the effect of transmembrane pressure and enzyme pre-treatment on the permeate flux, membrane fouling mechanism and juice quality on a laboratory scale. The quality parameters of clarified juice were clarity, color and phenolic content.

To determine the impact of transmembrane pressure and enzyme pre-treatment, several blocking mechanisms of a UF membrane using a recently developed membrane-fouling model $[21,22]$ were investigated.

Different fouling mechanisms were visualized (figure 1) [23]. When the pore size is smaller than the size of suspended particles in juice, the particle deposit on the external membrane surface entrances results in a complete or partial pore blocking (figures $1 a, 1 b)$, reducing membrane porosity and permeability. Subsequently, the accumulated particles can form aggregates. These particles grow in time, leading to the formation of a secondary membrane or cake (figure 1c). The thickness of this secondary membrane is responsible for an additional mass transport resistance which can be effectively controlled by an appropriate choice of fluid-dynamic conditions. The particles with a size range much smaller than that of the membrane pores will pass through. These particles may be adsorbed and deposited (figure 1d), leading to the for-

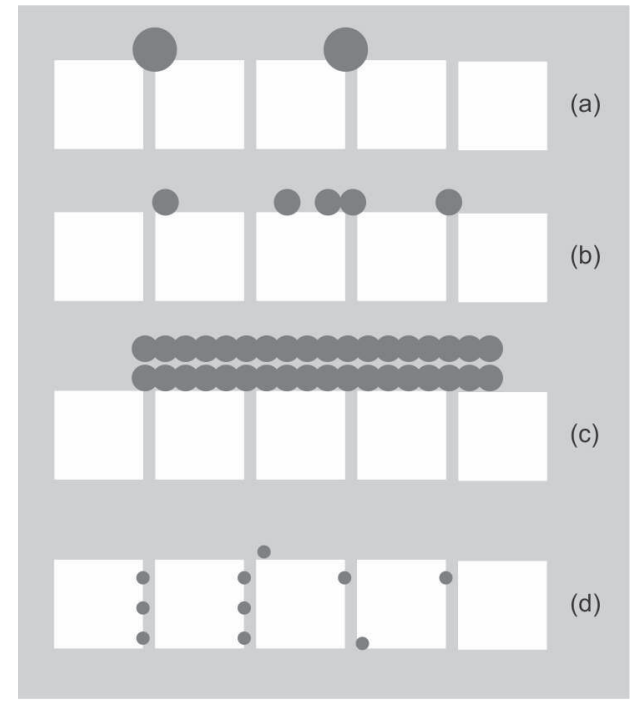

Figure 1

Mechanism for membrane fouling used for ultrafiltration treatment of pomegranate juice: (a) complete pore blocking; (b) partial pore blocking; (c) cake filtration; (d) internal pore blocking [23]. mation of a colloidal film on the internal pore surface [24]. The pore radius is reduced and the hydraulic resistance is increased.

A mathematical model which is able to describe the flux decline $(d J / d t)$ based on an equation applied to dead-end filtration mechanisms at constant pressure filtration has been proposed by Hermia [21] and modified by Field et al. [22]. This model accounts for the fouling mechanism involved in crossflow filtration, and has been used to describe fouling mechanisms in orange and pineapple juice [7, 25]. The general differential equation is the following: $-\frac{d J}{d t}=\left(k\left(J-J_{\lim }\right)\right) /\left(J^{n-2}\right), \quad$ where $J_{\lim }$ represents the limit flux obtained in steadystate conditions; $k$ and $n$ are phenomenological coefficients depending on the fouling mechanism. Values for the parameter $n$, depending on the type of fouling, are the following (figure 1): complete pore blocking $(n=2)$, partial pore blocking $(n=1)$, internal pore blocking $(n=3 / 2)$ and gel layer formation $(n=0)$. The constant $k$ depends on the transmembrane pressure, the dynamic permeate viscosity and the blocked areas per unit of permeate flux and the membrane resistance, $R_{m}$ [26]. The parameters considered by these models have a physical meaning and contribute to the comprehension of the mechanisms involved in membrane fouling. 


\section{Materials and methods}

\subsection{Fruit origin}

Pomegranate fruits (Punica granatum L.) of proper maturity and ripeness were supplied from a local market in Tunisia.

\subsection{Juice extraction}

The pomegranate fruits were washed and then manually cut up. Following peeling, the outer leathery skin that encloses the fleshy seeds was removed. The remaining pomegranate seeds were centrifuged by a Philips Electric juice centrifuge to obtain fresh juice. The $\mathrm{pH}$ and total soluble solids of the juice obtained were 4.1 and $15^{\circ}$ Brix, respectively. Raw juices were kept frozen at $-20{ }^{\circ} \mathrm{C}$ until analysis [27].

\subsection{Juice analysis}

Protein concentration in the pomegranate juice was measured by the Kjeldahl method using the conversion factor of 6.25. Pectin was determined by a method described by Englyst et al. [28]. Atomic absorption spectrophotometry (for $\mathrm{Cu}, \mathrm{Fe}, \mathrm{Zn}, \mathrm{Mg}$ and $\mathrm{Ca}$ ) and flame spectrophotometry (Sherwood, model 410) (for $\mathrm{Na}$ and $\mathrm{K}$ ) were used to measure mineral salts. Lipids were determined using the Soxhlet system [29]. The total sugar was measured by the colorimetric method using dinitrosalicilic acids (DNS). Total phenolics were determined with Folin-Ciocalteau (FC) reagent, and referred to as $\mathrm{mg} \cdot \mathrm{L}^{-1}$ of gallic acid [30]. Color (as absorbance at $420 \mathrm{~nm}$ on samples diluted by a factor of 5) [5, 16] and clarity (as absorbance at $650 \mathrm{~nm}$ ) [5] values were measured using a Shimadzu UV-VIS scanning spectrophotometer (UV-2101-PC) [27].

\subsection{Enzymatic pre-treatment}

Before ultrafiltration (UF), the juice was treated at $20{ }^{\circ} \mathrm{C}$ with Fomes fomentarius laccase (MUCL 35117) at a concentration of $5 \mathrm{U} \cdot \mathrm{mL}^{-1}$ for $300 \mathrm{~min}$. The optimum conditions of this pre-treatment were determined in a previous work using response surface statistical methodology [27]. At $20^{\circ} \mathrm{C}$, the viscosity values for the raw and treated juice are, respectively, (3.49 and 2.09) $\mathrm{mPa}^{-1} \mathrm{~s}^{-1}$.

\subsection{UF unit and procedures}

Pomegranate juice was clarified by using a laboratory pilot unit equipped with a crossflow filtration system implementing a tubular mineral CARBOSEP M2 membrane (stainless 31b membrane module, TechStep, France) (table I). The equipment consists of a feed tank, a thermometer, two manometers for the measurement of inlet and outlet pressures and a flow meter of 0 $2 \mathrm{~L} \cdot \mathrm{min}^{-1}$ for measurement of the axial feed flow rate $\left(Q_{f}\right)$ and, consequently, the tangential fluid velocity $\left(0-3.8 \mathrm{~m} \cdot \mathrm{s}^{-1}\right)$. All experiments were conducted at $20^{\circ} \mathrm{C}$. Transmembrane pressure (TMP) was controlled by the valve on the retentate side to give a pressure $(\mathrm{P})$ of $1-4$ bar and calculated as TMP $=\left(\mathrm{P}_{\text {in }}+\mathrm{P}_{\text {out }}\right) / 2$. Ultrafiltration experiments were performed according to the total recycle and the batch concentration mode. In the former, the experimental trials were devoted to the investigation of the effect of the transmembrane pressure on the flux performance of the system and quality of juice. In this case, the permeate was continuously recycled to the feed tank to ensure a steady state in the volume and composition of the feed. In the batch concentration mode, the UF system was operated at a TMP of 2 bar, at a tangential fluid velocity of $1 \mathrm{~m} \cdot \mathrm{s}^{-1}$ to study the effect of enzymatic treatment on the fouling during the clarification process up to a volume reduction factor (VRF) of about 6 units; VRF is defined as the ratio between the initial feed volume and the volume of the resulting retentate.

At the end of each run, cleaning-in-place was used for the membrane module according to the manufacturer's recommendations using caustic soda $\left(5-10 \mathrm{~g} \cdot \mathrm{L}^{-1} ; \mathrm{T}=80\right.$ $85^{\circ} \mathrm{C}$; operating time $=30 \mathrm{~min}$; $\mathrm{TMP}=2$ 3 bar) and nitric acid $\left(3-5 \mathrm{~mL} \cdot \mathrm{L}^{-1} ; \mathrm{T}=\right.$ $55-60{ }^{\circ} \mathrm{C}$; operating time $=30 \mathrm{~min}$; $\mathrm{TMP}=$ 2-3 bar). The membrane was exposed to this washing sequence until the original water flux was restored. 
Table I.

Characteristics of the CARBOSEP ultrafiltration membrane used for clarification of raw pomegranate juice.

\begin{tabular}{cccccc}
$\begin{array}{c}\text { Nominal molecular } \\
\text { weight cut-off } \\
(\mathrm{kDa})\end{array}$ & $\begin{array}{c}\text { Membrane area } \\
\left(\mathrm{cm}^{2}\right)\end{array}$ & $\begin{array}{c}\text { Length } \\
(\mathrm{cm})\end{array}$ & $\begin{array}{c}\text { Inner diameter } \\
(\mathrm{mm})\end{array}$ & $\mathrm{pH}$ operating range & $\begin{array}{c}\text { Water permeability } \\
\left(\mathrm{L} \cdot \mathrm{hm}^{-2} \cdot \mathrm{bar}^{-1}\right)\end{array}$ \\
\hline 15 & 75 & 40 & 6 & $1-14$ & 60
\end{tabular}

Table II.

Physicochemical analysis of unclarified pomegranate juice (amount $100 \mathrm{~g}^{-1}$ of raw juice).

\begin{tabular}{|c|c|c|c|c|c|c|c|c|c|c|c|c|}
\hline Proteins & Lipids & Total sugar & \multirow[t]{2}{*}{ Pectin } & Total phenols & Mineral salts & $\mathrm{Cu}$ & $\mathrm{Fe}$ & $\mathrm{Zn}$ & $\mathrm{Mg}$ & $\mathrm{Na}$ & $\mathrm{Ca}$ & K \\
\hline \multicolumn{3}{|c|}{ (g) } & & \multicolumn{2}{|c|}{ (g) } & \multicolumn{7}{|c|}{ (mg) } \\
\hline $0.96-1.20$ & $0.30-0.40$ & $10.18-12.02$ & traces & $1.2-1.8$ & $0.3-0.5$ & $\leq 0.08$ & $2.0-3.2$ & $0.3-0.4$ & $3-4.4$ & $25-34$ & $16-17$ & $356-466$ \\
\hline
\end{tabular}

The rejection $(\mathrm{R} \%)$ of the membrane is estimated by the relation: $R=100\left(1-\frac{C_{p}}{C_{0}}\right)$, where $C_{p}$ is the end concentration in the permeate $\left(\mathrm{mg} \cdot \mathrm{L}^{-1}\right)$ and $C_{O}$ is the initial concentration of the feed $\left(\mathrm{mg} \cdot \mathrm{L}^{-1}\right)$.

\subsection{Procedure for estimation of parameters $n$ and $k$}

The general differential equation:

$$
\frac{d J}{d t}=k\left(J-J_{\text {lim }}\right) / J^{n-2}
$$

is solved by an explicit, improved Euler scheme. The general form of this differential equation is $\frac{d J}{d t}=f(J, t)$. The numerical scheme used starts with an Euler step, giving a provisional value for $J_{i+1}$ at the next time $t_{i+1}$ :

$$
J_{i+1}=J_{i}+h f\left(t_{i}, J_{i}\right)
$$

The taken step actually looks like an Euler step, but with $f$ replaced by the average of $f$ at the starting point of the step and $f$ at the provisional point:

$$
J_{i+1}=J_{i}+\frac{h}{2}\left[f\left(t_{i}, J_{i}\right)+f\left(t_{i+1}, J_{i+1}\right)\right]
$$

The differential equation (1) displays two parameters, $k$ and $n$, that have to be determined. The basic operation of the optimization process is the minimization of the functional built from both experimental results and numerical simulation in order to characterize the "distance" between them. This minimized functional $\ell$ depends on the vector of the parameters $(n, k)$ and can be expressed as the sum of the elementary functional $\ell_{j}$, defined for each experimental test $(j)$ based on:

$$
\ell(n, k)=\sum_{j} \ell_{j}(n, k)
$$

The optimization procedure is as follows. The parameter $n$ is first assigned to some particular values ( $n=0,1,1.5$ and 2 ). Then, $k$ is adjusted to minimize the deviation between experimental and simulated data.

\section{Results and discussion}

Physicochemical analysis of unclarified pomegranate juice shows that there are three compounds, protein, lipids and phenolic compounds, responsible for fouling layer formation (table II). Proteins and polyphenolic compounds can combine to form soluble complexes, which may have colloidal sizes, and may scatter light, and can result in sediment formation [31]. 
Figure 2

Effect of the transmembrane pressure (TMP) used for ultrafiltration treatment of pomegranate juice on the permeate flux (temperature, $\mathrm{T}=20^{\circ} \mathrm{C}$; tangential velocity, $\left.\mathrm{V}_{\mathrm{m}}=1 \mathrm{~m} \cdot \mathrm{s}^{-1}\right)$.

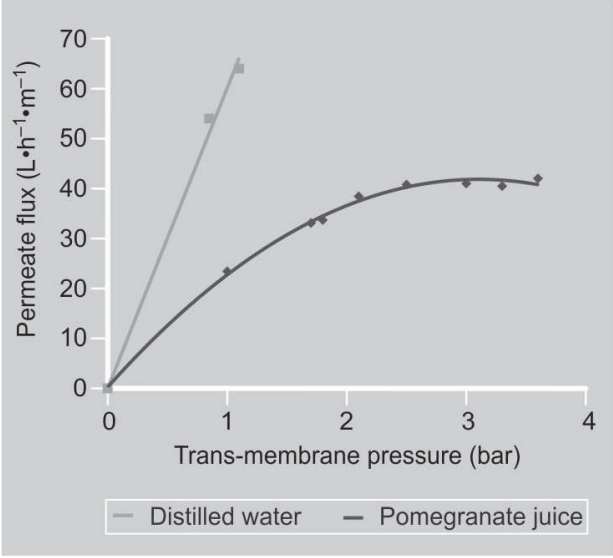

\subsection{Effect of transmembrane pressure on the permeate flux and clarified raw juice quality}

Ultrafiltration experiments, carried out according to the total recycle mode, were performed in order to study the effect of transmembrane pressure (TMP) on the permeate fluxes and permeate properties. Permeate flux values versus the applied TMP (figure 2) show that, for small pressures, the solvent flux is proportional to the applied pressure. As the pressure is increased, the flux shows a deviation from linear flux-pressure behavior and becomes independent of pressure. Under these conditions a limiting flux is reached at a TMP value of about 2 bar, and any further pressure increase determines no significant increase in the permeate flux. The existence of a limiting flux can be related to the fouling.
The effect of TMP on color and clarity of clarified pomegranate juice was significant (table III). Color is an important sensory attribute. The initial color of the raw pomegranate juice was reduced from $74 \%$ to $33 \%$ by UF when the TMP increased from (1 to 3.6) bar. Under the effect of pressure, the pigments responsible for the color can pass through the membrane and therefore they cause an increase in color [16].

Clarity is another important sensorial quality parameter for clarified juices. It may be observed that the initial clarity value of the raw pomegranate juice was improved by UF. The clarity decreased from $77 \%$ to $42 \%$ by UF when the TMP increased from (1 to 3.6) bar. This decrease in the clarity can be related to the increase in color when the transmembrane pressure increased.

Total phenolic rejection decreased from $45 \%$ to $21 \%$ when the TMP rose from (1 to 2) bar (table III), mainly because the more TMP, the higher the amount of solute flowing through the membrane. Increasing the TMP from (2 to 3 ) bar resulted in an increase in the amount of deposited fouling materials on the membrane surface, and consequently increasing total phenolic rejection. The fouling formed at a higher TMP can prevent the solute from crossing the membrane and, therefore, reduce the amount of phenolic compounds in the permeate, resulting in a decrease in the astringency and an increase in stability of the pomegranate juice. Mirsaeedghazi et al. showed that clarification of pomegranate juice using membranes decreased phenolic content for all

\section{Table III.}

Effect of transmembrane pressure (TMP) on the color clarity and phenolic compound rejection of clarified pomegranate raw juice at tangential velocity $\left(V_{m}\right)=1 \mathrm{~m} \cdot \mathrm{s}^{-1}$.

\begin{tabular}{lccc}
\hline $\begin{array}{l}\text { Transmembrane pressure } \\
\text { (bar) }\end{array}$ & Total phenolic rejection & Color reduction & Clarity improvement \\
\cline { 2 - 4 } & & $(\%)$ & \\
\hline 1.00 & 45.45 & 74.45 & 76.92 \\
1.70 & 25.72 & 46.50 & 56.41 \\
2.05 & 21.23 & 42.13 & 55.12 \\
2.45 & 23.31 & 38.00 & 51.92 \\
3.60 & 26.51 & 32.75 & 41.66 \\
\hline
\end{tabular}


membranes used [32]. The rejection factors vary between $25 \%$ and $50 \%$.

\subsection{Enzyme influence on the permeate flux and the quality of clarified juice}

When studying the performance batch system while processing the pomegranate juice with and without laccase pre-treatment, permeate flux versus time obtained with raw juice and juice pre-treated with enzyme decreased rather slowly at the initial stage and achieved a quasi-steady state afterwards (figure 3). The slow decline of permeate flux, attributed to fouling, could be explained by the fact that, in the early stage of UF, permeate flux is controlled by the internal fouling [11]. Membrane fouling is caused mainly by large constituents of the juice such as proteins and polyphenol-protein complexes. The pre-treatment improved the permeation flux (figure 3). The steadystate permeate flow increased by around $40 \%$ with enzyme treatment. Similar results were achieved with umbu juice pre-treated with enzyme before UF [33]. The final permeate of umbu juice increased by $25-35 \%$ with enzyme treatment at low velocity and high pressure or at high velocity and high pressure. Typical behavior was observed with apple juice pre-treated with enzyme followed by pasteurization. The permeate flux was increased by about $81 \%$ under the applied TMP of 2 bar and the cross-flow velocity of $2.5 \mathrm{~m} \cdot \mathrm{s}^{-1}$ [11].

The characteristics of the pomegranate juices obtained by different treatments show

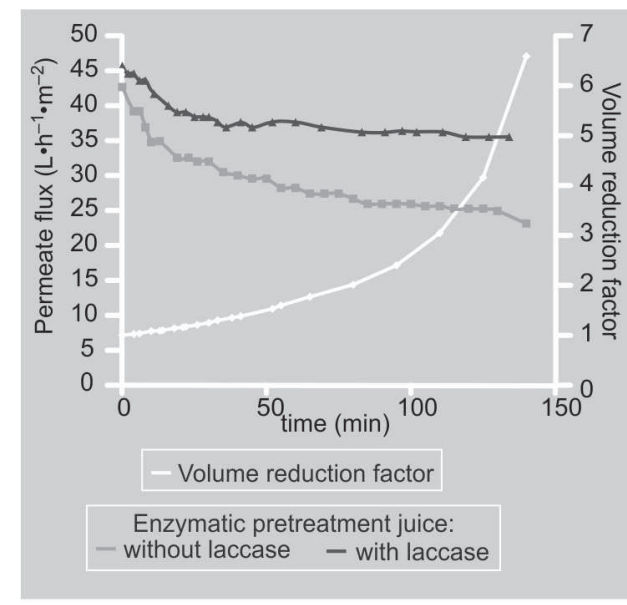

Figure 3

Variation of the permeate flux and volume reduction factor (VRF) with time for pomegranate juice treated by ultrafiltration at transmembrane pressure $(\mathrm{TMP})=2$ bar and tangential velocity $\left(V_{m}\right)=1 \mathrm{~m} \cdot \mathrm{s}^{-1}$. that the total phenolic rejection capacity was enhanced by enzymatic treatments (table IV). Total phenol rejection was 21\% for ultrafiltered, $38 \%$ for laccase-treated and $49 \%$ for laccase-UF-treated juice. It was reported by Giovanelli and Ravasini that the combined laccase-UF process removed $70 \%$ (cut-off value $15 \mathrm{kDa}$ ) of the total phenolics in apple juice [34].

The application of UF caused a notable decolorization in laccase-treated samples. However, laccase-UF-treated and only UFtreated pomegranate juice showed the same decrease in their color (35\%) compared with untreated samples (table IV). These results are in agreement with other authors [5, 20]. For example, Gokmen et al. reported that custom membranes caused a notable decolorization in both laccase-treated and control samples of apple juice (reduction in color varied from $28 \%$ to $45 \%$ ) [20]. The color of the samples was increased by $90 \%$

Table IV.

Characteristics of different pomegranate juices treated by enzymatic treatment or by ultrafiltration [transmembrane pressure $(\mathrm{TMP})=2$ bar; tangential velocity $(\mathrm{V})=1 \mathrm{~m} \cdot \mathrm{s}^{-1}$ ].

\begin{tabular}{|c|c|c|c|c|c|}
\hline \multirow{2}{*}{$\begin{array}{l}\text { Treated pomegranate } \\
\text { juice }\end{array}$} & Total phenolic rejection & Color increase & Color reduction & Clarity decrease & Clarity improvement \\
\hline & \multicolumn{5}{|c|}{$(\%)$} \\
\hline Ultrafiltered & 21 & - & 35 & - & 15 \\
\hline Laccase-treated & 38 & $90^{1}$ & - & $166^{1}$ & - \\
\hline Laccase-UF-treated & 49 & - & 38 & - & 32 \\
\hline
\end{tabular}




\section{Figure 4}

Effect of the volume reduction factor (VRF) on the permeate flux of pre-treated pomegranate juice treated by ultrafiltration [transmembrane pressure $(\mathrm{TMP})=2$ bar; temperature $(\mathrm{T})=20^{\circ} \mathrm{C}$; tangential velocity (V) $\left.=1 \mathrm{~m} \cdot \mathrm{s}^{-1}\right]$.

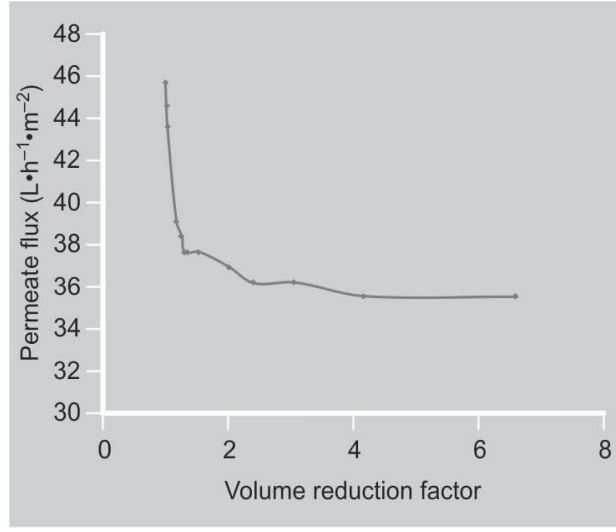

divided into three periods: firstly, the permeate flux decreases rapidly due to the concentration polarization. Secondly, the permeate flux decreases slightly up to a VRF equal to 4 , which corresponds with the beginning of the fouling. The last period of the curve is characterized by a steady-state flux due to complete fouling. These observations corroborate the results obtained by Cassano et al. for clarification of kiwi fruit and blood orange juice [25, 35].

\subsection{Fouling mechanism}

The best prediction for the fouling mechanism was obtained for pomegranate juice without laccase in the gel layer $(n=0$, $\left.k=0.025 \times 10^{-3}, R^{2}=0.9867\right)$ (table $V$ ). On the other hand, complete pore blocking ( $\left.n=2, k=53 \times 10^{-3}, R^{2}=0.9745\right)$ becomes the predominant fouling mechanism for pre-treatment of pomegranate juice. Very good agreement is observed between experimental and theoretical data (figure 5). On the basis of the results obtained, it can be concluded that the fouling mechanism is affected by the pre-treatment process, and the solute nature and size has an important role in the solute-membrane physicochemical interaction and, consequently, in the fouling mechanism. If the results are compared with those obtained by Mirsaeedghazi et al. [36], perfect agreement with the untreated juice is noted. Unlike after pre-treatment of pomegranate juice,

Table V.

Estimates of the model parameters $k$ and $n$ of pomegranate juice ultrafiltered with and without laccase (enzymatic pre-treatment).

\begin{tabular}{lccc}
\hline \multicolumn{1}{c}{$n$} & $k \times 10^{3}$ & $\begin{array}{c}\text { Measures of fit } \\
R^{2} \text { (ultrafiltered) }\end{array}$ & $\begin{array}{c}\text { Measures of fit } \\
R^{2} \text { (laccase-UF-treated) }\end{array}$ \\
\hline Complete pore blocking $(n=2)$ & 29 & 0.9732 & 0.9259 \\
Internal pore blocking $(n=1.5)$ & 53 & 0.9453 & 0.9745 \\
Partial pore blocking $(n=1)$ & 5 & 0.9796 & 0.9430 \\
Gel layer $(n=0)$ & 0.6 & 0.9747 & 0.9626 \\
& 1.5 & 0.9724 & 0.9082 \\
& 0.025 & 0.9688 & 0.9594 \\
& 0.020 & 0.9867 & 0.9697 \\
& & & 0.9544
\end{tabular}


the fouling mechanism can change during the filtration process due to the elimination of large particles by the pre-treatment [36].

\section{Conclusions}

Pomegranate juice was clarified by crossflow ultrafiltration (UF) using a tubular mineral membrane with a molecular weight cutoff of $15 \mathrm{kDa}$. The effect of transmembrane pressure (TMP) and enzymatic pre-treatment on the permeate flux and quality of clarified juice was investigated.

In the operating conditions (2 bar and $1 \mathrm{~m} \cdot \mathrm{s}^{-1}$ ), an average permeation flux of $36 \mathrm{~L} \cdot \mathrm{m}^{-2} \cdot \mathrm{h}^{-1}$ was obtained. Approximately $21 \%$ of polyphenolic compounds were retained; the initial clarity and color values of the raw pomegranate juice were, respectively, improved by $55 \%$ and reduced by $42 \%$. UF application of clarified pomegranate juice decreased the amount of phenolic compounds that cause astringency and bitterness, thus improving clarity but reducing the natural red color.

The pre-treatment improved the permeation flux. The combined laccase-UF process improved the rejection of polyphenols and clarity. However, laccase-UF-treated and only UF-treated pomegranate juice showed the same decrease in their color.

The evaluation of the fouling mechanism of ultrafiltration of pomegranate juice showed that cake formation and complete pore blocking are the main mechanisms responsible for membrane fouling, respectively, for pomegranate juice without and with enzyme pre-treatment. This evaluation can help to find the process and methods of membrane regeneration. The membrane permeability can be regained after following a proper cleaning procedure. For example, cake formation is a reversible fouling mechanism; it can be removed easily by washing with water. On the contrary, complete blocking is not a reversible fouling mechanism, though rinsing with strongly alkaline or acidic agents at elevated temperatures may help to remove fouling.

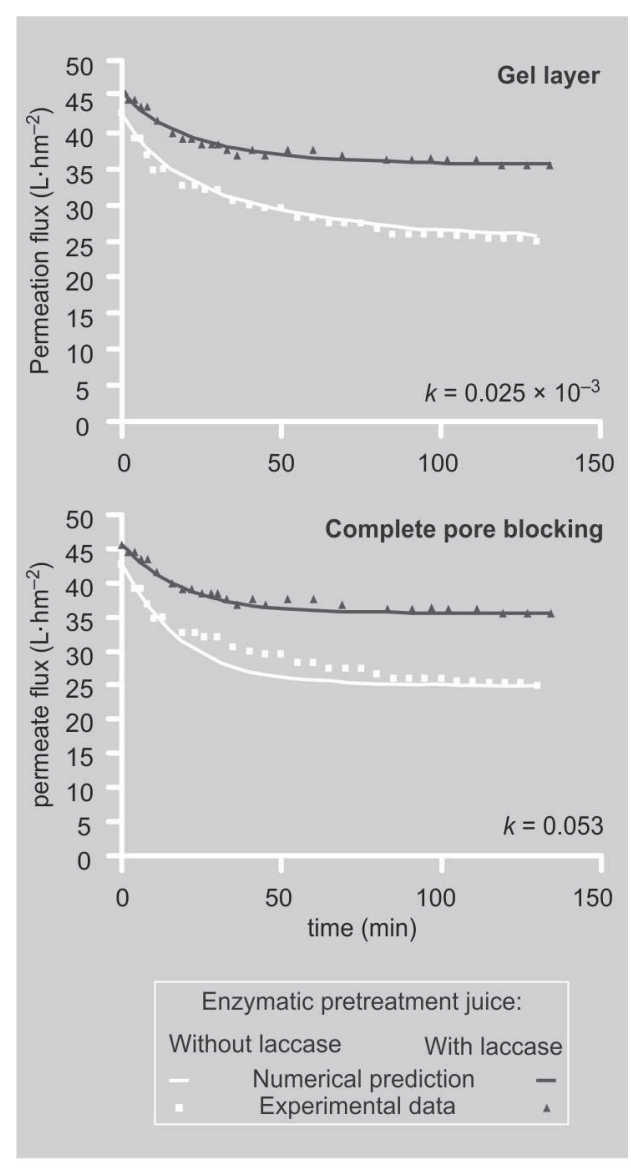

\section{Acknowledgments}

The authors acknowledge Prof. Kacem Saï for help with numerical modeling and parameter identification.

\section{References}

[1] Aviram M., Rosenblat M., Gaitini D., Nitecki S., Hoffman A., Dornfeld L., Volkova N., Presser D., Attias J., Liker H., Hayek T., Pomegranate juice consumption for 3 years by patients with carotid artery stenosis reduces common carotid intima-media thickness, blood pressure and LDL oxidation, Clin. Nutr. 23 (2004) 423-433.

[2] De Nigris F., Williams-Ignarro S., Lerman L.O., Crimi E., Botti C., Mansueto G., D'Armiento F.P., De Rosa G., Sica V., Ignarro L.J., Napoli C., Beneficial effects of pomegranate juice on oxidation-sensitive genes

\section{Figure 5}

Gel layer formation model $\left(n=0 ; k=0.025 \times 10^{-3}\right)$ and complete pore blocking $(n=2$; $k=0.053$ ) for cross-flow filtration predictions from pomegranate juice treated with or without laccase. 
and endothelial nitric oxide synthase activity at sites of perturbed shear stress, Proc. Natl. Acad. Sci. USA (PNAS) 102 (2005) 48964901.

[3] Rosenbalt M., Hayek T., Aviram M., Anti-oxidative effects of pomegranate juice consumption by diabetic patients on serum and on macrophages, Atherosclerosis 187 (2006) 363-371.

[4] Rouseff R.L., Bitterness in foods and beverage, Dev. Food Sci. 25 (1990) 1-12.

[5] Alper N., Acar J., Removel of phenolic compounds in pomegranate juices using ultra filtration and laccase-ultra filtration combinations, Nahr. 48 (2004) 148-187.

[6] Nawaz H., Shi J., Mittal G.S., Kakuda Y., Extraction of polyphenols from grape seeds and concentration by ultrafiltration, Sep. Purif. Technol. 48 (2006) 176-181.

[7] Bruijn J.P.F., Venegas A., Martinez J.A., Borquez R., Ultra filtration performance of carbosep membranes for the clarification of apple juice, LWT-Food Sci. Technol. 36 (2003) 397-406.

[8] Barros S.T.D., Andrade C.M.G., Mendes E.S., Peres L., Study of fouling mechanism in pineapple juice clarification by ultra filtration, J. Membr. Sci. 215 (2003) 213-224.

[9] Cassano A., Conidi C., Timpone R., D'Avella M., Drioli E., A membrane-based process for the clarification and the concentration of the cactus pear juice, J. Food Eng. 80 (2007) 914-921.

[10] Cheikh-Rouhou S., Baklouti S., Hadj-Taïeb N., Besbes S., Chaabouni S., Blecker C.,

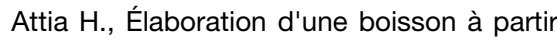
d'écart de triage de dates : clarification par traitement enzymatique et microfiltration, Fruits 61 (2006) 389-399.

[11] He Y., Ji Z., Li S., Effective clarification of apple juice using membrane filtration without enzyme and pasteurization pretreatment, Sep. Purif. Technol. 57 (2007) 366-373.

[12] Szaniawski A.R., Effects of pectin concentration and crossflow velocity on permeability in the microfiltration of dilute pectin solutions by macroporous titania membranes containing immobilised pectinase, Biotechnol. Prog. 12 (1996) 403-405.

[13] Vaillant F., Millan P., O'Brien G., Dornier M., Decloux M., Reynes M., Cross flow microfiltration of passion fruit after partial enzymatic liquefaction, J. Food Eng. 42 (1999) 215224.
[14] Vladisavljević G.T., Vukosavljević P., Bucvić B., Permeation flux and fouling resistance in ultrafiltration of depectinized apple juice using ceramic membranes, J. Food Eng. 60 (2003) 241-247.

[15] Yu J., Lencki R.W., Effect of enzyme treatments on the fouling behaviour of apple juice during microfiltration, J. Food Eng. 63 (2004) 413-423.

[16] Borneman Z., Gökmen V., Nijhuis H.H., Selective removal of polyphenols and brown colour in apple juices using PES/PVP membranes in a single ultrafiltration process, Sep. Purif. Technol. 23 (2001) 53-61.

[17] Chaisakdanugull C., Theerakulkait C., Wrolstad R.E., Pineapple juice and its fractions in enzymatic browning inhibition of banana [Musa (AAA Group) 'Gros Michel'], J. Agric. Food Chem. 55 (2007) 4252-4257.

[18] Pinelo M., Landbo A.K.L., Vikbjerg A.F., Meyer A.S., Effect of clarification technique and rat intestinal extract incubation on phenolic composition and antioxidant activity of black currant juice, J. Agric. Food Chem. 54 (2006) 6564-6571.

[19] Oszmianski J., Lee C.Y., Enzymatic oxidative reaction of catechin and chlorogenic acid in a model system, J. Agric. Food Chem. 38 (1990) 1202-1204.

[20] Gökmen V., Borneman Z., Nijhuis H.H., Improved ultrafiltration for colour reduction and stabilization of apple juice, J. Food Sci. 63 (1998) 504-507.

[21] Hermia J., Constant pressure blocking filtration laws application to power-law non-Newtonian fluids, Trans. Inst. Chem. Eng. 60 (1982) 183-187.

[22] Field R.W., Wu D., Howell J.A., Gupta B.B., Critical flux concept for microfiltration fouling, J. Membr. Sci. 100 (1995) 259-272.

[23] Field R.W., Wu D., Howell J.A., Gupta B.B., Mass transport and the design of membrane system, in: Scott K., Hughes R. (Eds.), Industrial membrane separation technology, Chapman \& Hall, Lond., U.K., 1996, 93 p.

[24] Wei D.S., Hossain M., Saleh Z.S., Separation of polyphenolics and sugar by ultrafiltration: Effects of operating conditions on fouling and diafiltration, Int. J. Chem. Biomol. Eng. 1 (2008) 9-16.

[25] Cassano A., Marchio M., Drioli E., Clarification of blood orange juice by ultrafiltration: analyses of operating parameters, membrane fouling and juice quality, Desalination 212 (2007) 15-27. 
[26] Vela M.C.V., Blanco S.Á., García J.L., Rodríguez E.B., Analysis of membrane pore blocking models adapted to cross-flow ultrafiltration in the ultrafiltration of PEG, Chem. Eng. J. 149 (2009) 232-241.

[27] Neifar M., Ellouze-Ghorbel R., Kamoun A., Baklouti S., Mokni A., Jaouani A., EllouzeChaabouni S., Effective clarification of pomegranate juice using laccase treatment optimized by response surface methodology followed by Ultra filtration, J. Food Process. Eng. (2009) 1-21.

[28] Englyst H.N., Quigley M.E., Hudson G.J., Determination of dietary fibres as non starch polysaccharides with gaz-liquid chromatography, high performance liquid chromatographic or spectrophotometic measurment of constituent sugars, Analyst. 119 (1994) 1497-1509.

[29] Anon., Official methods of analysis, Assoc. Off. Anal. Chem. (AOAC), 16th ed., Wash., D.C, U.S.A., 1997.

[30] Singleton V.L., Rossi Jr. J.A., Colorimetry of total phenolics with phosphomolybdic acid reagents, Am. J. Enol. Vitic. 16 (1965) 144158.
[31] Siebert K.J., Troukhanova N.V., Lynn P.Y., Nature of polyphenol-protein interaction, J. Agric. Food Chem. 44 (1996) 80-85.

[32] Mirsaeedghazi H., Emam-Djomeh Z., Mousavi S.M., Ahmadkhaniha R., Shafiee A., Effect of membrane clarification on the physicochemical properties of pomegranate juice, Int. J. Food Sci. Technol. 45 (2010) 1457-1463.

[33] Ushikubo F.Y., Watanabe A.P., Viotto L.A., Microfiltration of umbu (Spondias tuberosa Arr. Cam.) juice, J. Membr. Sci. 288 (2007) 61-66.

[34] Giovanelli G., Ravasin G., Apple juice stabilization by combined enzyme membrane filtration process, LWT-Food Sci. Technol. 26 (1993) 1-7.

[35] Cassano A., Jiao B., Drioli E., Production of concentration kiwifruit juice by integrated membrane process, Food Res. Int. 37 (2004) 139-148.

[36] Mirsaeedghazi H., Emam-Djomeh Z., Mousavi S. M., Aroujalian A., Navidbakhsh M., Changes in blocking mechanisms during membrane processing of pomegranate juice, Int. J. Food Sci. Technol. 44 (2009) 2135-2141.

\section{Clarificación del jugo granada por ultrafiltración: estudio de la calidad del jugo y del mecanismo de colmatación.}

Resumen - Introducción. La ultrafiltración (UF) es un proceso simple para la clarificación y el afinamiento de jugos de frutas. Su objetivo consiste en eliminar las materias en suspensión, así como las sustancias que inducen enturbiamiento y turbidez durante su almacenaje. Concretamente, la polimerización de los compuestos fenólicos y su interacción con otros componentes (proteínas, por ejemplo) podrían causar enturbiamiento y turbidez en los jugos de fruta, dando lugar a la colmatación de la membrana de ultrafiltración. Material y métodos. Se clarificó un jugo fresco de granada por ultrafiltración. Los ensayos experimentales se efectuaron a modo de reciclaje total o por lotes, por reenvío del concentrado en la cuba de alimentación. Se estudiaron los efectos de la presión transmembrana (PTM), así como los de un pretratamiento enzimático en el flujo de permeación y en la calidad de los jugos. Resultados. Con el modo de reciclaje total, el efecto de la PTM en el color y en la claridad del jugo de granada clarificado fue significativo. El color del jugo de granada puro se redujo del $74 \%$ al $33 \%$ y su claridad disminuyó de un $77 \%$ a un $42 \%$, cuando la PTM pasó de $(1$ a 3,6) bar. El desecho de los compuestos fenólicos disminuyó de un $45 \%$ a un $21 \%$ cuando la PTM pasó de ( 1 a 2 ) bar y se mantuvo constante por encima de 2 bar. En modalidad de tratamiento por lotes y con una PTM de 2 bar y una velocidad de $1 \mathrm{~m} \cdot \mathrm{s}^{-1}$, el tratamiento enzimático $\left(5 \mathrm{U} \cdot \mathrm{mL}^{-1}, 300 \mathrm{~min}, \mathrm{~T}=20^{\circ} \mathrm{C}\right)$ del jugo de granada mejoró el flujo de permeado y dio lugar a una disminución de los compuestos fenólicos totales del $50 \%$ y a un aumento de la claridad del $30 \%$. La colmatación de la membrana de UF durante el tratamiento del jugo de granada se debe principalmente a la retención de los polifenoles y/o de proteínas. En consecuencia, se han estudiado varios mecanismos de colmatación, empleando un modelo de colmatación de membrana desarrollado recientemente. El análisis reveló que el proceso de separación de la membrana estuvo controlado por el mecanismo de la capa de gel, para el jugo de granada puro, y por un mecanismo de bloqueo completo de los poros, para el jugo con pretratamiento enzimático.

Túnez / Punica granatum / jugo de frutas / clarificación / ultrafiltración / compuestos fenólicos / membrana / incrustación / procesamiento / lacasa 